\title{
Estimates of genetic parameters for grain yield, various yield components and some quality traits in rice (Oryza sativa $\mathrm{L}$.)
}

\author{
Gaurav Kamboj ${ }^{1}$, Pradeep Kumar ${ }^{2 *}$ and Devi Singh ${ }^{1}$ \\ ${ }^{1}$ Department of Genetics and Plant Breeding, Sardar Vallabhbhai Patel University of Agriculture and Technology, \\ Meerut-250110 (Uttar Pradesh), INDIA \\ ${ }^{2}$ Crop Improvement Division, Indian Institute of Wheat and Barley Research, Karnal-132001 (Haryana), INDIA \\ *Corresponding author. E-mail: pradeeptaliyan231@gmail.com
}

Received: August 3, 2017; Revised received: December 29, 2017; Accepted: February 20, 2018

\begin{abstract}
A study was conducted during two crop season (Kharif, 2011-12 and 2012-13) for estimating the genetic parameters by involving 10 parents and their $45 \mathrm{~F}_{1} \mathrm{~s}$ in rice crop. The estimates of $\mathrm{h}^{2}$ (overall dominance effects) were positive and significant for days to $50 \%$ flowering (9.11), days to maturity (0.24), plant height (2.95), panicle length1(39), productive tillers per plant (3.22), branches per panicle (5.61), flag leaf area (5.50), 1000-grain weight (0.27), biological yield (7.35) and amylose content (1.03) which indicated dominance of genetic components in $F_{1} s$ crosses. The theoretical value $(0.25)$ of $\left(\mathrm{H}_{2} / 4 \mathrm{H}_{1}\right)$ for all the traits except kernel length and amylose content indicated the asymmetrical distribution of positive and negative genes in the parents. The proportion of dominant and recessive alleles for panicle length, productive tillers, branches per panicle, 1000 grain weight, biological yield, kernel length and L/B ratio reflected more dominant alleles, whereas for days to $50 \%$ flowering, days to maturity, plant height, grains per panicle, flag leaf area, grain yield, harvest index, kernel breadth, kernel length after cooking, elongation ratio, amylose content and hulling \%, reflected more recessive alleles in the parents. The estimates of specific combining ability (SCA) effects revealed that the cross Vallabh Basmati $21 \times$ Pusa 1121 could be an excellent candidate for improving grain yield $\left(1.52^{* *}\right)$, harvest index $\left(1.86^{* *}\right)$ and flag leaf area $\left(6.20^{* *}\right)$ whereas Pusa $1121 \mathrm{x}$ CSR 10 is excellent candidate for panicle length $\left(0.89^{* *}\right)$ and amylose content $\left(1.54^{* *}\right)$. The characters showing more than $60 \%$ narrow sense heritability along with positive and significant correlation with each other and also with grain yield could be rewarding for further improvement of yield and quality in rice. Therefore, these parental lines can be used as donors in future by following bi-parental mating and the diallel selective mating system could be the best breeding method in an early segregating generation for improvement in these traits in rice crop.
\end{abstract}

Keywords: Rice, Half-diallel, Genetic components, Gene action, Yield components and quality traits

\section{INTRODUCTION}

Rice (Oryza sativa L.) is the third most cultivated crop in terms of area and second most important in terms of production in the world. In India, as per the $4^{\text {th }}$ advance estimates of 2016-17, rice is cultivated in an area of 43.38 million hectares with the production of 104.32 million tones and average productivity of $2404 \mathrm{~kg}$ per hectares as compare to the production of 105.32 million hectares, from an area of 43.90 million hectares and average productivity of $2390 \mathrm{~kg}$ per hectares during the preceding years 2015-16 (Anonymous, 2016). The combining ability determined through diallel analysis which is useful to assess the nicking ability of parents, and at the same time, it also determined the nature and magnitude of different types of gene actions involved in the expression of various yield components. Combining ability analysis also helps to evaluate the breeding lines in terms of their genetic value, selection of suitable parents for hybridization and iden- tification of superior cross combinations. The general combining ability gives the information about additive and additive $\mathrm{x}$ additive gene action, whereas specific combining ability provides information about the nonallelic interaction and dominance gene action. Diallel crossing program has been applied to achieve this goal by providing a systematic approach for detection of suitable parents and crosses for the investigated characters. Also, the diallel analysis gives plant breeders the opportunity to choose the most efficient selection method by allowing them to estimate several genetic parameters by Singh and Chaudhary (1979). The main objective here was to drawn information on nature and type of gene action, the contribution of various yield component and some quality traits towards grain yield in rice. The information drawn on gene action would be effectively exploited to develop an appropriate breeding programme for continued genetic improvement in rice (Oryza sativa L), for evolving new geno- 
types with higher grain yield and ultimate good nutritional quality for eating purpose.

\section{MATERIALS AND METHODS}

The base materials consists of ten diverse genotypes of rice (Oryza sativa L.) namely, Vallabh Basmati 21, Vallabh Basmati 22, MAUB 57 collected from SVPUA and T Meerut, Pusa 1121, Pusa Basmati 1, Pusa 1401 collected from IARI-New Delhi, CSR 30, CSR 13 CSR 10 collected from CSSRI-Haryan and Basmati 370 from Rice Research Station-Haryan, was planted at Crop Research Centre, SVPUA\&T Meerut during kharif season (2011-12) for attempting crossing in a $10 \times 10$ half-diallel fashion (excluding reciprocals) to generate the materials. In the next crop season $\mathrm{kha}$ rif, (2012-2013) experimental materials consisted of 55 genotypes ( 10 parents and $45 \mathrm{~F}_{1} \mathrm{~s}$ ) was sown in a Randomized Block Design with three replications to evaluate the materials. 25 days old seedling of each parental lines and $\mathrm{F}_{1} \mathrm{~s}$ were planted in a two rows plot of 2 meter length maintaining the spacing of $15 \mathrm{~cm}$ between plants within a row and $25 \mathrm{~cm}$ between rows. All the standard agronomical practices (recommended dose of fertilizers, irrigations, and weed management practices) were followed to raise a normal crop. The observations were recorded on five randomly selected plants from each genotype in each replication on various yield components and some quality characters viz., days to $50 \%$ flowering, days to maturity, plant height $(\mathrm{cm})$, panicle length $(\mathrm{cm})$, number of productive tillers per plant, number of branches per panicle, number of grains per panicle, flag leaf area $\left(\mathrm{cm}^{2}\right), 1000$-grain weight $(\mathrm{g})$, biological yield per plant $(\mathrm{g})$, grain yield per plant $(\mathrm{g})$, harvest index $(\%)$, kernel length $(\mathrm{mm})$, kernel breadth $(\mathrm{mm}), \mathrm{L} / \mathrm{B}$ ratio, kernel length after cooking ( $\mathrm{mm}$ ), elongation ratio, amylose content, hulling per cent and the mean values for all the characters was used for statistical analysis. Components of genetic variance were calculated as per the methods suggested by Hayman (1954). The analysis of variance was calculated by the methods suggested by Panse and Sukhamte, (1967). The combining ability analysis was calculated following the method-2 and model-1 suggested by Griffing, (1956). The expectations in biometrical scale for various statistics were worked out following the Hayman, approach (1954). D: (variation due to genetic effects), $\mathrm{H}_{1}$ : (variation due to dominance genetic effects), $\mathrm{H}_{2}$ : (proportion of $+/$-genes), $\mathrm{F}$ : (mean covariance of additive and dominance effects), $\mathrm{h}_{2}$ (overall dominance effects) and $\mathrm{E}$ (variation due to environmental effects). Related statistics of components of variance included (i) Average degree of dominance $\left(\mathrm{H}_{1} / \mathrm{D}\right)^{1 / 2}$, (ii) proportion of genes with positive and negative effects in the parents $\left(\mathrm{H}_{2} / 4 \hat{\mathrm{H}}_{1}\right)$, (iii) proportion of dominant and recessive genes in the parents, $\mathrm{F}$ being insignificantly different from zero $\left[(4 \mathrm{D} \mathrm{H})^{0.5}\right.$ $\left.+\mathrm{F} /(4 \mathrm{D} \mathrm{H})^{1 / 2}-\mathrm{F}\right]$ and (iv) number of groups of genes control the characters and exhibited dominance $\left(\mathrm{h}_{2} /\right.$ $\mathrm{H}_{2}$ ).

\section{RESULTS AND DISCUSSION}

The results obtained for testing the significance of variance among the treatments by " $F$ " test and mean squares and other parameters are presented (Table 1). The variances due to treatments were further partitioning into their orthogonal components namely, parents, hybrids and parents vs hybrids. The " $F$ " test indicated that variance due to treatments; parents and hybrids were highly significant (at $<1 \%$ level of significance) for all the characters under study. The analysis of variance was highly significant (at $<1 \%$ level of signifi-

Table 1. Analysis of variance for parents and $\mathrm{F}_{1} \mathrm{~s}$ for various yield components and some quality traits in rice.

\begin{tabular}{|c|c|c|c|c|c|c|c|}
\hline Character & $\begin{array}{l}\text { Replication } \\
(\mathrm{d} \mathbf{f}=2)\end{array}$ & $\begin{array}{l}\text { Treatments } \\
(\mathrm{d} \mathrm{f}=54)\end{array}$ & $\begin{array}{l}\text { Parents } \\
(\mathrm{d} f=9)\end{array}$ & $\begin{array}{l}\text { Hybrids } \\
(\mathrm{d} f=44)\end{array}$ & $\begin{array}{l}\text { Parents Vs } \\
\text { hybrids }(\mathrm{d} \text { f=1) }\end{array}$ & $\begin{array}{l}\text { Error } \\
(d \mathrm{f}=108)\end{array}$ & $\begin{array}{l}\text { Total } \\
(\mathrm{d} \mathrm{f}=164)\end{array}$ \\
\hline Days to $50 \%$ flowering & 0.08 & $48.14 * *$ & $86.74 * *$ & $39.76 * *$ & $69.39 * *$ & 0.44 & 16.14 \\
\hline Days to maturity & 0.51 & $10.56 * *$ & $17.44 * *$ & $9.47 * *$ & $2.10 *$ & 0.34 & 3.71 \\
\hline Plant height & 0.13 & $668.24 * *$ & $1323.84 * *$ & $548.79 * *$ & $23.11 * *$ & 0.89 & 220.61 \\
\hline Panicle length & 0.08 & $8.92 * *$ & $17.22 * *$ & $7.18 * *$ & $10.55 * *$ & 0.05 & 2.97 \\
\hline Productive tillers & 0.07 & $14.43 * *$ & $26.70 * *$ & $11.69 * *$ & $24.73 * *$ & 0.36 & 4.99 \\
\hline Branches per panicle & 1.66 & $2.86 * *$ & $3.29 * *$ & $1.86 * *$ & $42.91 * *$ & 0.48 & 1.27 \\
\hline Grains per panicle & 19.24 & $2009.76 * *$ & $3577.32 * *$ & $1723.48 * *$ & $497.86 * *$ & 10.32 & 668.78 \\
\hline Flag leaf area & 4.15 & $17.65 * *$ & $10.78 * *$ & $18.48 * *$ & $43.11 * *$ & 1.52 & 6.86 \\
\hline 1000 -grain weight & 0.04 & $4.03 * *$ & $3.62 * *$ & $4.15 * *$ & $2.46^{*}$ & 0.48 & 1.65 \\
\hline Biological yield & 1.44 & $443.67 * *$ & $918.70 * *$ & $355.31 * *$ & $56.32 * *$ & 0.72 & 146.58 \\
\hline Grain yield & 0.05 & $64.45 * *$ & $118.65 * *$ & $54.78 * *$ & $2.12 * *$ & 0.25 & 21.39 \\
\hline Harvest index & 0.42 & $80.15 * *$ & $150.62 * *$ & $67.39 * *$ & $7.46 * *$ & 0.34 & 26.62 \\
\hline Kernel length & 0.01 & $0.67 * *$ & $1.36 * *$ & $0.55 * *$ & 0.01 & 0.01 & 0.22 \\
\hline Kernel breadth & 0.01 & $0.01 * *$ & $0.01 * *$ & $0.01 * *$ & 0.00 & 0.00 & 0.00 \\
\hline $\mathrm{L} / \mathrm{B}$ ratio & 0.01 & $0.36 * *$ & $0.73 * *$ & $0.29 * *$ & 0.01 & 0.01 & 0.12 \\
\hline Kernel length after cooking & 0.02 & $3.65 * *$ & $6.26 * *$ & $3.19 * *$ & $0.15 * *$ & 0.02 & 1.22 \\
\hline Elongation ratio & 0.02 & $0.03 * *$ & $0.04 * *$ & $0.01 * *$ & $0.01 * *$ & 0.00 & 0.01 \\
\hline Amylose content & 0.26 & $3.07 * *$ & $5.81 * *$ & $2.39 * *$ & $8.09 * *$ & 0.36 & 1.25 \\
\hline Hulling per cent & 0.04 & $4.78 * *$ & $8.56 * *$ & $4.09 * *$ & $1.05 * *$ & 0.06 & 1.61 \\
\hline
\end{tabular}

* Significant at $5 \%$ probability level, $* *$ Significant at $1 \%$ probability level 
Gaurav Kamboj et al. / J. Appl. \& Nat. Sci. 10 (1): 459 - 465 (2018)




Gaurav Kamboj et al. / J. Appl. \& Nat. Sci. 10 (1): 459 - 465 (2018)

Table 3. Specific combining ability effects and gene action for various yield components and some quality traits in rice.

\begin{tabular}{|c|c|c|c|c|c|}
\hline \multirow{2}{*}{ Trait } & \multirow{2}{*}{ Cross } & \multirow{2}{*}{$\begin{array}{l}\text { SCA } \\
\text { effect }\end{array}$} & \multicolumn{2}{|c|}{ GCA effect } & \multirow{2}{*}{$\begin{array}{l}\text { Type of gene } \\
\text { action }\end{array}$} \\
\hline & & & $\mathrm{P}_{1}$ & $\mathrm{P}_{2}$ & \\
\hline Days to $50 \%$ flowering & Vallabh Basmati 22 x MAUB 57 & $-0.80 *$ & $3.99 * *$ & $5.10 * *$ & Non additive \\
\hline Days to maturity & Vallabh Basmati 21 x Pusa 1401 & $-1.28^{*}$ & $-0.61 * *$ & $-0.24 * *$ & additive \\
\hline Plant height & Vallabh Basmati 21 x Pusa Basmati 1 & $-0.61^{*}$ & $1.83^{* *}$ & $-1.56 * *$ & Non additive \\
\hline Panicle length & Pusa 1121 x CSR 10 & $0.89 * *$ & $0.20 * *$ & $-1.99 * *$ & Non additive \\
\hline Productive tillers & Vallabh Basmati 21 x Basmati 370 & $1.32 * *$ & $-1.23 * *$ & $2.72 * *$ & Non additive \\
\hline Branches per plant & Basmati 370 x CSR 10 & $1.32 * *$ & 0.01 & -0.04 & Non additive \\
\hline Grains per panicle & Vallabh Basmati 22 x Pusa 1121 & $38.10 * *$ & $-14.68 * *$ & $-22.62 * *$ & Non additive \\
\hline Flag leaf area & Vallabh Basmati 21 x Pusa 1121 & $6.20 * *$ & $0.69 * *$ & $1.31 * *$ & Additive \\
\hline 1000-gain weight & MAUB 57 x Pusa 1121 & $0.87 *$ & $0.27 *$ & $0.68 * *$ & Additive \\
\hline Biological yield & MAUB 57 x CSR 10 & $2.42 * *$ & $5.42 * *$ & $-15.72 * *$ & Non additive \\
\hline Grain yield & Vallabh Basmati 21 x Pusa 1121 & $1.52 * *$ & $3.56^{* *}$ & $-1.79 * *$ & Non additive \\
\hline Harvest index & Vallabh Basmati 21 x Pusa 1121 & $1.86^{* *}$ & 1.5 & $-0.88 * *$ & Non additive \\
\hline Kernel length & CSR $13 \times$ CSR 10 & 0.0 & -0.4 & -0.6 & Non additive \\
\hline Kernel breath & CSR $30 \times$ Basmati 370 & $0.01 * *$ & $0.03 * *$ & $-0.03 * *$ & Non additive \\
\hline $\mathrm{L} / \mathrm{B}$ ratio & Vallabh Basmati 21 x CSR 30 & $0.04 * *$ & $0.10^{* *}$ & $-0.08 * *$ & Non additive \\
\hline Kernel length after cooking & Vallabh Basmati 21 x Vallabh Basmati 22 & $0.61 * *$ & $0.91 * *$ & $0.45^{* *}$ & Additive \\
\hline Elongation ratio & Vallabh Basmati $22 \times$ CSR 10 & $0.08 * *$ & $0.03 * *$ & $-0.01 * *$ & Non additive \\
\hline Amylose contain & Pusa 1121 x CSR 10 & $1.54 * *$ & $0.48 * *$ & $-0.74 * *$ & Non additive \\
\hline Hulling percentage & Pusa 1401 x CSR 10 & $0.59 *$ & $-0.91 * *$ & $1.14^{* *}$ & Non additive \\
\hline
\end{tabular}

*, $* *$ Significant at $5 \%$ and $1 \%$ probability level, $\mathrm{SCA}=$ Specific Combining Ability, GCA= General Combining Ability

cance) among the treatments, parents and hybrids for days to $50 \%$ flowering, days to maturity, plant height, panicle length, productive tillers, branches per panicle, grains per panicle, flag leaf area, 1000 grain weight, biological yield, grain yield, harvest index, kernel length, kernel breadth, L/B ratio, kernel length after cooking, elongation ratio, amylose content and hulling per cent. The variances due to parents vs hybrids were also highly significant (at $<1 \%$ level of significance ) for all the characters except kernel length, kernel breadth and $\mathrm{L} / \mathrm{B}$ ratio revealed that the significant variability available in the present set of breeding material that allowed us for further partitioning of genetic effects. The understanding of variability and genetic architecture of a population is of considerable importance in formulating effective breeding programme. The estimated values of all the genetic components of variance namely, $\mathrm{D}, \mathrm{H}_{1}, \mathrm{H}_{2}, \mathrm{~h}^{2}, \mathrm{~F}$ and $\mathrm{E}$ along with their standard error and related parameters are presented in (Table 2). The estimates of additive component (D) of variance was found significant (at $<5 \%$ level of significance ) for 18 characters namely, days to $50 \%$ flowering, days to maturity, plant height, panicle length, productive tillers, branches per panicle, grains per panicle, 1000 grain weight, biological yield, grain yield, harvest index, kernel length, kernel breadth, L/B ratio, kernel length after cooking, elongation ratio, amylose content and hulling per cent in $\mathrm{F}_{1}$ generation, indicating the predominance of additive gene action in the inheritance of these traits. The estimates of dominance components $\left(\mathrm{H}_{1}\right.$ and $\left.\mathrm{H}_{2}\right)$ of genetic variance were also found significant (at $<5 \%$ level of significance ) for 14 characters namely, days to $50 \%$ flowering, plant height, panicle length, productive tillers, branches per panicle, grains per panicle, 1000-grain weight, biological yield, grain yield, harvest index, kernel breadth, L/B ratio, kernel length after cooking, elongation ratio in $F_{1}$ generation, indicating the predominance of additive gene action in the inheritance of these traits. The estimates of $\mathrm{H}_{1}$ were higher than the estimates of $\mathrm{H}_{2}$ for all the characters except amylose content $(\mathrm{H} 1=0.12$ and $\mathrm{H} 2=0.14)$ indicating the unequal allelic frequencies at relevant loci in the population. These results indicated that both additive and dominance gene action played an important role in the inheritance of these characters. Additive and dominance gene action is responsible for the inheritance of different yield components and quality traits in rice (Mahmood et al., 2004 and Sajad et al., 2014). The analysis of variance components indicates that both additive and dominance components are significant for almost all the characters under study; however, dominance components were more predominant than additive components of variance.

The positive and significant (at $<5 \%$ level of significance ) values of F-component of genetic variance for, panicle length, branches per panicle, biological yield, kernel length, kernel breath and $\mathrm{L} / \mathrm{B}$ ratio in $\mathrm{F}_{1 \mathrm{~s}}$ crosses indicated the role of dominant and positive alleles in the parents for improving these characters. Whereas grains per panicle, grain yield, harvest index, kernel length, kernel breadth, L/B ratio, kernel length after cooking and hulling per cent showed positive but nonsignificant values of F-components of genetic variance which indicated that there was partial dominance. Positive and significant values of F-component were also reported by Sajad et al. (2014) for kernel length and kernel L/B ratio whereas positive and non-significant values for grains per panicle, grain yield, harvest index and kernel breadth in rice crop. 
The estimated values of $h^{2}$ were positive and significant (at $<5 \%$ level of significance) for 11 characters namely, days to $50 \%$ flowering, days to maturity, plant height, panicle length, branches per panicle, flag leaf area, 1000-grain weight, biological yield and amylose content which indicating the dominance of genetic components in $\mathrm{F}_{1} \mathrm{~s}$, whereas non-significant values of $\mathrm{h}^{2}$ were observed for remaining characters, indicating the partial dominance of genetic components. The positive and significant values of $h^{2}$ for days to maturity, plant height and panicle length while positive but non-significant for productive tillers was also reported (Mahmood et al., 2004). Whereas positive and significant values of $\mathrm{h}^{2}$ for days to $50 \%$ flowering, days to maturity, plant height whereas positive but non -significant values for grain yield, harvest index, grains per panicle and kernel L/B ratio were also reported (Sajad et al., 2014) in rice crop these both earlier findings support the results of present study.

The environmental component (E) were nonsignificant for ten yield and quality traits viz., days to $50 \%$ flowering, panicle length, grain per panicle, flag leaf area, biological yield, grain yield, harvest index, kernel length after cooking elongation ratio and hulling per cent in $F_{1}$ generations indicated that there are no environmental effects in the inheritance of these traits. The estimates of the average degree of dominance expressed as $\left(\mathrm{H}_{1} / \mathrm{D}\right)^{1 / 2}$ were found to be more than unity in $F_{1 s}$ crosses for branches per panicle, flag leaf area and 1000-grain weight, indicating the preponderance of over dominance type of gene action for the inheritance of these characters. The average degree of dominance for days to $50 \%$ flowering, days to maturity, plant height, panicle length, productive tillers, grains per panicle, biological yield, grain yield, harvest index, kernel length, kernel breadth, L/B ratio, kernel length after cooking, elongation ratio, amylose content and hulling per cent was less than unity but greater than zero which indicating the importance of partial dominance for the inheritance of these characters. The importance of the average degree of dominance (both over-dominance and partial dominance) was earlier reported by Mahmood et al. (2004) for plant height and productive tillers in rice.

The proportion of genes with positive and negative effects in the parents $\left(\mathrm{H}_{2} / 4 \mathrm{H}_{1}\right)$ was found less than its theoretical value $(0.25)$ for days to $50 \%$ flowering, days to maturity, plant height, panicle length, productive tillers, branches per panicle, grains per spike, flag leaf area,1000-grain weight, biological yield, grain yield, harvest index, kernel breadth, L/B ratio, kernel length after cooking, elongation ratio, and hulling per cent in the $F_{1 \mathrm{~s}}$ crosses indicating asymmetrical distribution of positive and negative genes in the parents. The earlier findings in supports of present results for days to $50 \%$ flowering, days to maturity, plant height, grains per panicle, panicle length, productive tillers, biological yield, grain yield, harvest index and L/B ratio was also reported (Sajad et al., 2014) in rice crop. The estimates of the ratio $\left[\left(4 \mathrm{D} \mathrm{H}_{1}\right)^{0.5}+\mathrm{F} /\left(4 \mathrm{D} \mathrm{H}_{1}\right)^{1 / 2}-\mathrm{F}\right]$ which indicates that the proportion of dominant and recessive alleles among the parents was more than unity $(>1)$ for seven characters namely, panicle length, productive tillers, branches per panicle, 1000 grain weight, biological yield, kernel length and L/B ratio indicating the role of more dominant alleles in the parents for these characters. Whereas this ratio was less than unity $(<1)$ for 12 characters namely, days to $50 \%$ flowering, days to maturity, plant height, grains per panicle, flag leaf area, grain yield, harvest index, kernel breadth, kernel length after cooking, elongation ratio, amylose content and hulling per cent reflecting the role of more recessive alleles in the parents for these characters. The present results confirm with the earlier findings (Najeeb et al., 2011 and Sajad et al., 2014 ) in rice crop. The estimates of ratio $\mathrm{h}^{2} / \mathrm{H}^{2}$ (No. of gene groups) was more than unity for days to $50 \%$ flowering, days to maturity, plant height, productive tillers, branches per panicle, biological yield and amylose content in $\mathrm{F}_{1 \mathrm{~s}}$ crosses, indicating the involvement of more than one major gene groups are responsible for inheritance of these characters. Whereas this ratio was less than unity for grains per spike, flag leaf area, 1000-grain weight, grain yield, harvest index, kernel length, kernel breadth, L/B ratio, kernel length after cooking, elongation ratio, and hulling per cent in $F_{1 s}$ crosses indicating the involvement of single gene group in the inheritance of these characters. Similar findings for grains per panicle, grain yield, harvest index, kernel length, kernel breadth and L/B ratio was also reported (Sajad et al., 2014) in rice crop.

The narrow-sense heritability was higher for days to $50 \%$ flowering $(95 \%)$, days to maturity $(95 \%)$, plant height $(99 \%)$, panicle length $(92 \%)$, productive tillers $(90 \%)$, grains per panicle $(90 \%)$, flag leaf area $(67 \%)$, 1000-grain weight (74\%), biological yield $(99 \%)$, grain yield (98\%), harvest index (96\%), kernel length (99\%), kernel breadth (97\%), L/B ratio (99\%), kernel length after cooking (92\%), elongation ratio $(80 \%)$, amylose content $(85 \%)$ and hulling per cent $(93 \%)$ whereas branches per panicle (41\%) showed moderate heritability. The selection for these traits will be rewarding in further generations for improvement in rice crop. High estimates of heritability (narrow sense) were also reported for plant height and moderate heritability for a number of branches per plant (Mahmood et al., 2004). High heritability for plant height and harvest index (Verma and Srivastava, 2004) whereas high heritability for grain length (Sajad et al. 2014) also reported in rice crop. High heritability for days to $50 \%$ flowering, plant height, panicle length, grains per panicle, harvest index, 1000-grain weight and grain yield in rice also reported (Kumar et al., 2016) whereas high heritability for kernel length, kernel breath, $\mathrm{L} /$ 
$\mathrm{B}$ ratio, kernel length after cooking and amylose content was reported (Savitha and Kumari, 2016).

In the present study, we select the best specific cross combination for each trait, and the results are presented in (Tabel 3). The trait wise specific combining ability (SCA) effects revealed that the cross namely, Vallabh Basmati 21 x Pusa 1121 showed highest positive and significant SCA effects for flag leaf area, harvest index and grain yield; Pusa 1121 x CSR 10 for panicle length and amylose content. The other crosses exhibiting highest positive and significant SCA effects for single trait wise are, Basmati 370 x CSR 10 for number branches per plant; Vallabh Basmati 22 x MAUB 57 for days to $50 \%$ flowering (early flowering type); Vallabh Basmati 21 x Pusa 1401 for days to maturity; Vallabh Basmati 21 x Pusa Basmati 1 for plant height and Vallabh Basmati 21 x Basmati 370 for productive tillers. Vallabh Basmati $22 \times$ Pusa 1121 for grains per panicle; CSR 13 x CSR 10 for kernel length ; MAUB $57 \times$ CSR 10 for biological yield; MAUB 57 x Pusa 1121 for 1000-grain weight and CSR $30 \times$ Basmati 370 for kernel breath; Vallabh Basmati 21 x CSR 30 for L/B ratio; Vallabh Basmati 21 x Vallabh Basmati 22 for kernel length after cooking; Vallabh Basmati 22 $\mathrm{x}$ CSR 10 for elongation ratio and Pusa 1401 x CSR 10 for hulling per cent (Table 3 ). These individual crosses may be exploited in heterosis breeding programme to improve the trait of interest in rice crop. The earlier findings in support of present results for SCA/GCA effects were also reported (Roy and Senapati, 2012; Singh et al., 2013; Kumari et al., 2014; Menaka and Ibrahim, 2016; Aditya and Bhartiya, 2017) in rice. The traits which showed dominance or non-additive type of gene effects might be improved by inter-mating the most desirable segregates followed by selection. Whereas, traits that exhibited a predominance of nonadditive gene effects would require maintaining considerable heterozygosity through mating of the selected plant in early segregating generations to attain maximum genetic gain. Therefore, few cycles of recurrent selection followed by pedigree breeding would be effective for the improvement of grain yield.

\section{Conclusion}

Based on the findings of the present study, it may be concluded that both additive (fixable) and non-additive (non-fixable) components of genetic variances were involved in governing the inheritance of almost all the quantitative traits under study in the present set of materials. Generation advancement of selected $\mathrm{F}_{1} \mathrm{~s}$ crosses showing highest SCA effects and further hybridization involving parents with good GCA effects into multiple crossing combinations may involve yield and quality traits. Therefore, bi-parental mating and/or diallel selective mating which may allow inter-mating of the selects in different cycles and exploit both additive and non-additive gene effects would be useful in the improvement of the trait in rice crop. The traits namely, days to $50 \%$ flowering, days to maturity, plant height, panicle length, productive tillers, grains per panicle, flag leaf area, 1000-grain weight, biological yield, grain yield, harvest index, kernel length, kernel breadth, L/B ratio, kernel length after cooking, elongation ratio, amylose content and hulling per cent showed high narrow sense heritability (more than 60\%) and also exhibited positive and high significant correlation with grain yield (at $<1 \%$ level of significance) indicating greater role of additive genetic components. Therefore, selection for these traits in an early generation would be effective for the improvement of yield and quality traits and the information generated from the present study will help in formulating a breeding programme to develop high yielding and better quality rice genotypes.

\section{REFERENCES}

Anonymous (2016). Annual reported 2016-17, departments of agriculture, cooperation and farmers welfare, 1-10 pp ministry ad agriculture and farmers welfare, government of India, new delhi-110001.

Aditya, J.P. and Bhartiya, A. (2017). Estimation of combining ability for yield and yield component traits in upland rice (Oryza Sativa L.) of Uttarakhand hills. Journal of Applied and Natural Science, 9(1): 406-414.

Griffing, B. (1956). A generalized treatment of the use of diallel crosses in quantitative inheritance. Heredity, 10: 31-50.

Hayman, B.I. (1954). The theory and analysis of diallel crosses. Genetics, 39(6):789-809.

Kumar, P., Nautiya, M.K. and Kumar, P. (2016). Gene action and component of genetic variance analysis in the thermo sensitive genetic male sterile (TGMS) line in rice (Oryza sativa L.). Journal of Applied and Natural Science, 8(4): 2011-2015.

Kumari, P., Jaiswal, H.K. and Waza, S.A. (2014). Combining ability and heterosis for yield, its component traits and some grain quality parameters in rice (Oryza sativa L.). Journal of Applied and Natural Science, 6(2): 495-506

Mahmood, T., Turner, M., Stoddard, F.L. and Javed, M.A. (2004). Genetic analysis of quantitative traits in rice (Oryza sativa L.) exposed to salinity. Australian Journal of Agricultural Research, 55: 1173-1181.

Menaka, J. and Ibrahim, S.M. (2016). Combining ability for yield and different quality traits in rice (Oryza sativa L.). Journal of Applied and Natural Science, 8(4): 22982304.

Najeeb, S., Zargar, M.A., Rather, A.G., Sheikh, F.A., Ahangar, M.A. and Rezvi, M.H. (2011). Combining ability study in rice (Oryza sativa L.) Under temperate conditions of Kashmir. Electronic Journal of Plant Breeding, 2(1): 31-40.

Panse, V.G. and Sukhatme, P.V. (1967). Statistical Methods of Agricultural Workers. 2nd Endorsement, ICAR Publication, New Delhi, India, pp: 381

Roy, S.K. and Senapati, B.K. (2012). Combining ability analysis for grain yield and quality characters in rice (Oryza sativa). Indian Journal of Agricultural Sciences, 82(4): 
Gaurav Kamboj et al. / J. Appl. \& Nat. Sci. 10 (1): 459 - 465 (2018)

293-303.

Sajad, H.D., Rather, A.G., Najeeb, S., Zeerak, N.A., Shikari, A.B., Bhat, Z.A., Ahanger, M.A., Mir, S.D., Ahmad, M., Iqbal, S., Saba, I. and Hassan, G. (2014). Gene action and standard heterosis over environments in Rice (Oryza sativa L.). Electronic Journal of Plant Breeding, 5(3): 360-370.

Savitha, P. and Kumari, R.U. (2016). Genetic variability studies in segregating generation for grain and nutrition- al quality traits in rice (Oryza sativa L.). Journal of Applied and Natural Science, 8(1): 63-68.

Singh, R.K. and Chaudhary, B.D. (1979). Biometrical Methods in Quantitative Genetic Analysis. Kalyani Publisher, New Delhi. Pp318.

Singh, M.K., Singh, R.P. and Singh, P. (2013). Identification of good combiners in early maturing $\mathrm{x}$ high yielding cultivars of Indica rice (Oryza sativa L.). Bangladesh journal of botany, 42(2): 247-255. 